stood amongst psychologists as in the world at large.

In the final chapter, switching from solid, textbook prose to a question-andanswer format suggesting the world's most degree-laden agony aunt, Jensen treats the reader to a glimpse into his postbag.

- "My father is a world-recognized genius. Yet I am sure he would flunk any IQ test. What do you think of that?"

- "What can I do for my child to raise his IQ?"'

"Is our national IQ declining?"

No doubt these are genuine extracts from letters the originals of which are available for inspection at the author's premises. The format of this chapter certainly conveys the impression of an attempt to provide a plain man's guide, but at the same time shows up the failure of the enterprise as a whole. For what Jensen has done is not to strip off inessential technicalities to reach a wider audience, but to present himself as the man in the white coat and invite confidence in his knowledge and expertise. He lacks neither, but the suspicion always lurks that he is too much of an interested party to be wholly dispassionate.

Steve Blinkhorn, a Senior Lecturer in Psychology at Hatfield Polytechnic, is currently working at the Neuropsychology Laboratory, Stanford University.

\section{The naturalist's art}

\section{T.R. Halliday}

ART and natural history have always been closely associated. But, over the past hundred years, illustrations have fulfilled a variety of functions in the natural history literature; the purpose of some is simply to aid identification, of others to be purely decorative and of yet more to encapsulate some aspect of the natural way of life of the creature portrayed. A number of recently published books not only enable us to trace the development of art in natural history from the nineteenth century to the present day, but to see how different artists have been concerned with one of these aims more than another.

A new, selected reprint of the Reverend F. O. Morris's British Birds, first published in parts between 1850 and 1857 , serves to show how far natural history illustrations have progressed in the past 130 years. This reprint (Webb \& Bower/Holt, Rinehart \& Winston; $£ 20, \$ 40$ ) has a brief introduction by Tony Soper, describing the aims of Morris's work and its impact on the public of his time. The coloured engravings by A.F. Lydon often bear only superficial resemblance to their subjects, the poses being wooden and unnatural; they can have been of little value as guides to the identification of living birds in the field. The worth of a reprint such as this is entirely historical. The book is of no use as a guide for a modern bird watcher but does, through its text, give an insight into the understanding that early ornithologists had of birds.

An artist generally recognized as one of the early masters of bird painting was John Gould, who died in 1873. A beautifully produced volume, John Gould's Birds (A\&W Publishers, New York; \$39.95 until December $1981, \$ 50$ thereafter), reproduces a rich selection of his finer work. Maureen Lambourne's introduction provides a biographical sketch of this productive and much-travelled artist. Gould's paintings are essentially decorative and are mostly in the form of vignettes, with the subject posed against foliage or a hint of landscape. Some of his work was remarkably ambitious, such as his painting of a barn swallow feeding her young in flight. His cock pheasant, far from being shown in its customary splendour, is portrayed lying dead in a snare. Gould's scrupulous attention to detail shows, not only in his birds, but also in the plants with which rnany are framed. Though his pictures are often stilted and contrived by today's standards, Gould's skill and accurate observations make this book a pleasure to look through.

The latest tribute to Archibald Thorburn, who died in 1885 (Thorburn's Landscape by John Southern, published by Elm Tree Books at $£ 12.50$ ), reproduces many of his larger paintings, in which as much attention is devoted to the landscape as to the birds. Most of the paintings are of game birds and are set in moorland, mountains and forest. Thorburn's skilful treatment of light, dark and colour beautifully evokes the chill of autumn or the bleakness of a snow-covered mountain side. Like Gould, Thorburn sometimes attempted a painting more ambitious than a posed group of birds, such as a peregrine killing a mallard in flight or a group of ptarmigan cowering as an unseen golden eagle casts its shadow over them. His rich use of colour and intimate knowledge of the habits of birds make this a fine book.

Following his death in 1979, a number of books have been published that display the work of Charles Tunnicliffe. Robert Gillmor edits and introduces the latest of them, Sketches of Bird Life (Gollancz; 10.95). Most of the book is devoted to Tunnicliffe's field sketches that provided the raw material for his major paintings. An interesting feature of this book is the way that it shows how the artist developed his work from field sketch to finished painting; more examples of this would have been welcome. The sketches, mostly in pencil or watercolour, reveal that Tunnicliffe was not only a supreme artist, but also a fine ethologist. Behavioural interactions between birds are beautifully recorded, both visually and in the annotations that appear on many of the sketches. Tunnicliffe's extreme devotion to his art was remarkable, as shown by his meticulous paintings of dead birds which, together with his field sketches, he used in the creation of his finished paintings.

The work of a new, living artist is presented in Keith Brockie's Wildlife Sketchbook (Dent/Macmillan, New York; £9.50, \$19.95). Working in Scotland, Brockie has carried on the Tunnicliffe tradition, never missing an opportunity to record a scene, a flower, a piece of driftwood or a dead bird, as well as patiently sketching living animals from a hide. Working mostly in pencil, crayon and watercolour, Brockie has the gift of being able to catch the essence of an animal, whether it is a bird, a fish or a rabbit. All that this attractive book lacks are some examples of how the artist might use his sketches to produce more formal paintings.

In sharp contrast, the contemporary American artist Robert Bateman specializes in huge paintings, beautifully

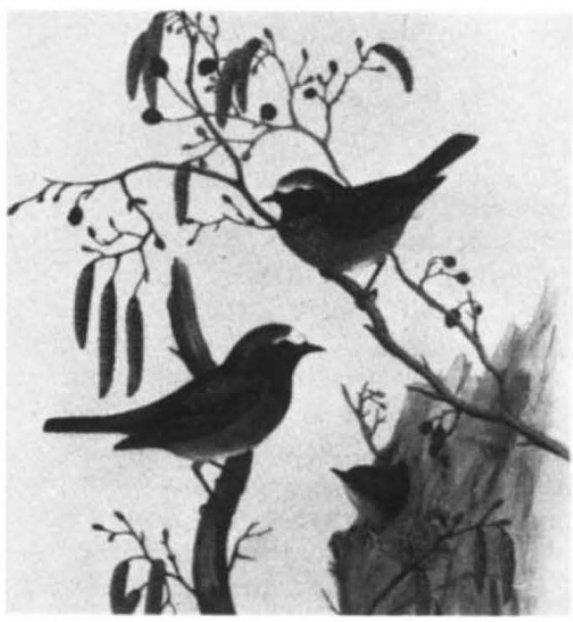

Three redstarts (Phoenicurus phoenicurus phoenicurus) painted by John Gould.

reproduced in The Art of Robert Bateman with text by Ramsay Derry (Viking/Allen Lane; $\$ 40, £ 20$ ). Bateman's breathtaking pictures are not pretty portraits of animals. His aim is clearly to emphasize the close relationship between an animal and its environment and, in many of his paintings, the animals seem to take second place to the landscape. There is much variety in the scope of his view, from panoramic vistas of Arctic tundra or the East African plains to restricted glimpses up into a tree or through the window of a derelict house. Bateman is an artist of many skills. Not only are his birds and mammals painted with exquisite accuracy of detail and posture, but his use of light and colour perfectly captures the icy cold of the tundra and the heat of the Serengeti plain. These are remarkable paintings that repay long and careful study, and this book stimulates a keen desire to see the original works.

Tim Halliday is a Lecturer in Biology at the Open University, and an author and illustrator of a number of books on natural history including Sexual Strategy (Oxford University Press, 1980) and Vanishing Birds (Penguin, 1980). 